\title{
Ethnic Enclaves, Education, and Crime among Immigrant Youth
}

\author{
Are Skeie Hermansen ${ }^{1,2}$ \\ ${ }^{1}$ Department of Sociology and Human Geography, University of Oslo \\ ${ }^{2}$ Swedish Institute for Social Research (SOFI), Stockholm University
}

May 2020

ABSTRACT. While the spatial concentration of immigrant minorities raises concern about the intergenerational consequences of place-based ethnic inequalities, influential theories of assimilation emphasize that mobilization of social capital within local ethnic networks is central in shaping the future life chances of immigrant youth. This study asks how properties of the ethnic neighborhood environment in adolescence predict future criminal behavior and educational careers among immigrant youth using rich administrative data from Norway. I find that immigrant youth's adolescent exposure to better-educated coethnic immigrant neighbors from the same origin country is related to lower risks of criminal engagement, higher likelihoods of completing upper-secondary education, and better academic achievements while growing up in areas with less-educated coethnics is associated with adverse outcomes. These associations are robust to adjustment for a broad set of background characteristics and fixed effects at the level of neighborhoods and national-origin groups. By contrast, the educational characteristics of other immigrant and native majority neighbors during adolescence seems to matter less. Overall, these findings support the view that the socioeconomic profile of coethnic neighbors in adolescence are consequential for key dimensions of immigrant youth's assimilation.

Acknowledgments: This research was supported by the Research Council of Norway [grant number 236793] and NordForsk [grant number 95263]. Earlier versions of this paper was presented at University of Oxford, Columbia University, University of Oslo, and the 2018 Population Association of America (PAA) Annual Meeting in Denver, CO, USA.

Please direct correspondence to Are Skeie Hermansen, Department of Sociology and Human Geography, University of Oslo, PO Box 1096, Blindern, NO-0317 Oslo, Norway. Email: a.s.hermansen@sosgeo.uio.no 


\section{INTRODUCTION}

Newcomer immigrants often settle in close proximity to earlier arrivals from their own origin country, thus contributing to spatially concentrated coethnic immigrant communities - often referred to as 'ethnic enclaves' (Andersson et al. 2018; Aradhya et al. 2017; Hall 2013; Musterd 2005). Research on 'neighborhood effects' shows that residential contexts shape adolescent development through processes such as interaction within friendship networks, the function of adult residents as role models and agents of social control, and the quality of schools or other local institutions (Harding et al. 2011; Jencks and Mayer 1990; Sampson, Morenoff and Gannon-Rowley 2002; Sharkey and Faber 2014). Since many immigrant minorities live in areas characterized by relative social deprivation, there is concern about the consequences of relative isolation from mainstream society and whether structural barriers related to spatial segregation contribute to the reproduction of place-based inequalities across immigrant generations (Alba and Foner 2015; Drouhot and Nee 2019; Kalter et al. 2018; Waters and Pineau 2015).

Although cohesive immigrant communities may contribute to upward social mobility and protect against detrimental outcomes, a relative lack of local 'ethnic capital' and exposure to disadvantaged neighbors could heighten the risk of educational disadvantage, youth delinquency, and broader patterns of downward assimilation (Borjas 1995; Cutler, Glaeser and Vigdor 2008; Portes and Rumbaut 2001). Recently, Sharkey and Faber (2014: 562) argued that "a single neighborhood is experienced in different ways by groups [...] who spend their time within the neighborhood in different ways and in their own spaces, carving out unique social worlds from the common environment that surrounds them." How immigrant youth from different minority groups who grow up in the same area are embedded in different ethnic networks is one aspect of such within-neighborhood variation. Thus, processes such as differential ex- 
posure to social control, transmission of norms and aspirations, or access to after-school tutoring may create local resources and risks specific to members of each minority group over and above broader neighborhood effects.

While ethnographic research often stress how resourceful immigrant communities help facilitate the incorporation of immigrant youth (e.g., Friberg 2019b; Kasinitz et al. 2008; Lee and Zhou 2015; Zhou and Bankston 1998), a small literature has sought to quantify how ethnic enclaves affect educational outcomes. Typically, these studies find that immigrant youth who grow up alongside well-educated and resourceful co-ethnic immigrant neighbors fare better in school, while the opposite is true for those living in socioeconomically disadvantaged local communities (Bygren and Szulkin 2010; Conger, Schwartz and Stiefel 2011; Fleischmann et al. 2013; Kroneberg 2008; Lee 2018; Åslund et al. 2011). Bygren and Szulkin (2010), for example, find that either beneficial or harmful effects of ethnic enclaves on schooling reflect the educational skills of coethnics and are stronger in larger communities, while another study finds that the positive influence of resourceful neighbors "travel most easily within co-ethnic networks [while] resources held by neighbours of different ethnic groups are less effective for individual attainment" (Fleischman et al. 2013: 1248). Relatedly, prior studies linking exposure to co-ethnic immigrant peers in school to various externalizing problem behaviors-e.g., not following rules, skipping school, coming late or arguing with teachers-find less problem behavior in school contexts where immigrant youth are surrounded by many co-ethnics (Benner and Crosnoe 2011; Georgiades, Boyle and Fife 2013; Geven, Kalmijn and van Tubergen 2016). To date, however, research has not systematically investigated how criminal behavior among immigrant youth is shaped by the characteristics of their ethnic neighborhood environment. Despite a few exceptions (Bygren and Szulkin 2010; Åslund et al. 2011), extant research on 
educational outcomes is seldom able to disentangle the influence of ethnic enclaves from neighborhood sorting and broader contextual effects shared by all immigrant youth living in the same area.

In this study, I develop testable hypotheses on how neighborhood exposure to co-ethnic immigrant networks matter for completion of upper-secondary education and criminal behavior among immigrant youth. I then test these predictions, examining how features of the adolescent ethnic environment predicts future outcomes among immigrant youth in a variety of nationalorigin minorities using administrative data from Norway $(43,891$ immigrant youth nested across 1,457 neighborhoods and 155 national-origin groups). These population-wide, spatially nested data enables me to measure how characteristics of local ethnic environments (e.g., the average educational attainment of adult coethnic immigrant neighbors from the same country of origin, as well as corresponding measures for neighboring immigrants from other origin countries and members of the native majority) vary across national-origin minorities who live in the same area. Group-specific variation within neighborhoods, enables me to examine how immigrant youth's later-life outcomes varies as a function of the local educational resources in their coethnic neighborhood community, as well as how this influence compares to that exerted by immigrant neighbors from other origin countries and local member of the native majority. Finally, this also allows me to estimate fixed-effects regressions that control for unobserved factors at the level of both residential areas and national-origin groups (cf. Bertrand, Luttmer and Mullainathan 2000).

\section{BACKGROUND}

Influential theories of immigrant assimilation emphasize how mobilization of social capital within local ethnic networks influence future life chances of immigrant youth (Borjas 1992, 
1995; Portes and Rumbaut 2001; Portes and Zhou 1993). While collective efficacy in local communities is likely to be important for migrants and nonmigrants alike (Sampson, Morenoff and Earls 1999), such networks are arguably often tighter within areas where immigrants who emigrated from the same country - often for similar reasons - continue to live close to each other. The spatial concentration of coethnic immigrant communities likely leads to high degrees of so-called 'intergenerational closure' (Coleman 1988; Portes 1998)—where neighboring youth and adults know each other well and social network structures are dense and closedwhich provides effective contexts for upholding mutual norms and controlling in-group behavior. A key question, however, is whether the direction of such ethnic enclave effects are conditioned by the local socioeconomic resources of fellow group members (Cutler et al. 2008).

Borjas $(1992,1995)$ formalized such an argument with the theoretical concept of 'ethnic capital' — where intergenerational mobility across immigrant generations is modeled as a function of both parental socioeconomic resources and the group-level quality of the ethnic environment in which parents make their investments. Mobilization of social capital within ethnic enclaves is perhaps most effective for immigrant groups that are socioeconomically diverse and where cross-class ties at the level of neighborhoods are common, as less resourceful members of the group can then benefit from proximity to more advantaged members of the group (Cutler et al. 2008). By contrast, reliance on in-group networks in disadvantaged immigrant minorities where group-level diversity is limited and resources are scarce may accentuate intergenerational disadvantage (Alba and Foner 2015; Heath 2007).

Segmented assimilation theory (Portes and Rumbaut 2001; Portes and Zhou 1993) also stresses how social, human, and economic resources—or lack thereof-found within ethnic enclaves are central to understand diverging assimilation trajectories among minority youth . The mobilization of ethnic social capital and 'selective acculturation' within cohesive commu- 
nities may foster upward mobility and insulate immigrant youth against detrimental outcomes - such as early school leaving and delinquent behaviors - if strong extrafamilial supervision preserves cultural values and group solidarity (Zhou and Bankston 1998). Local norms of high educational achievement may pressure immigrant youth to put more effort into schooling and raise their aspirations, while organized tutoring and supplementary after-school programs is also common within many immigrant minorities (Friberg 2019b; Kasinitz et al. 2008; Lee and Zhou 2015).

Further, the segmented assimilation perspective also highlights how absence communitylevel social control and coethnic resources may push disadvantaged minority youth towards 'downward assimilation' (Portes and Rumbaut 2001). If disadvantaged coethnics develop an adversarial stance towards mainstream society_-perhaps due to experiences of (perceived) ethnic discrimination and a sense of blocked opportunities - normative pressure may lead immigrant youth to devalue schooling, engage in delinquent behavior, and form oppositional ethnic identities (Bisin et al. 2011). Moreover, a lack of support from resourceful coethnics may also render immigrant youth especially vulnerable to exposure to high rates of adolescent crime often found in disadvantaged areas (DiPietro and McGloin 2012; Haynie, Silver and Teasdale 2006; Vogel and South 2016; Zimmerman and Messner 2011). To sum up, the key prediction about the link between ethnic neighborhood environment and immigrant youth's educational careers and criminal behavior can be formulated as:

HYPOTHESIS 1 (enclave composition): Immigrant youth who grow up in ethnic enclaves with high shares of well-educated and resourceful immigrant neighbors from the same origin country are less likely to engage in adolescent crime and more likely to have better educational outcomes.

Ethnic enclaves are likely to matter more in areas with many immigrants from the same origin group, as this may lead to increased group solidarity and contact among coethnics. A 
stylized fact from social network research is that people prefer to interact with and form friendships with individuals of the same ethnic background as they are (perceived) to be more similar with respect to tastes, worldviews, and behaviors (Lewis 2015; McFarland et al. 2014; McPherson, Smith-Lovin and Cook 2001). Further, the number of coethnic neighbors is an important structural determinant for daily opportunities to meet members of the same ethnic group and maintain in-group contact in a local context (Blau 1977; Feld 1981). Specifically, several studies report that immigrant youth often report that their closest friends belong to their own ethnic group and, more broadly, that ethnoracial friendship homophily increases disproportionately with rising exposure to more same-ethnic peers in school and neighborhood contexts (Currarini, Jackson and Pin 2010; Kruse and Kroneberg 2019; Moody 2001; Mouw and Entwisle 2006; Smith et al. 2016). If ethnic affiliation structures the local pattern and intensity of social interactions, the daily experiences and group-level resources available in the same neighborhood may be unique to each immigrant minority. Thus, we might expect a gradient of ethnic distance where spatial proximity to coethnic neighbors is more important than exposure to immigrants from other origin countries (Markussen and Røed 2015). Based on the above conjectures on how ethnic affiliation and group size structure local social interactions, I also expect that:

HYPOTHESIS 2 (ethnic affiliation): Educational resources of immigrant neighbors from other origin countries matter less of immigrant youth's outcomes compared to of co-ethnic neighbors.

HYPOTHESIS 3 (group size): Educational resources of co-ethnic neighbors matter more for immigrant youth's outcomes in areas with more immigrants from the same origin country.

Disentangling the hypothesized group-specific ethnic enclave effects from other sources of potential bias can be analytically difficult. A key challenge is that all neighboring youth are exposed to many shared contexts regardless of ethnic affiliation. This makes it difficult to 
isolate the group-specific influence of co-ethnic immigrant community from broader neighborhood effects, such as the presence of low-quality schools in many immigrant dense areas (Hermansen and Birkelund 2015; Portes and MacLeod 1996; Schwartz and Stiefel 2011). Ethnic enclave effects may also be confounded by unobserved characteristics shared all immigrant youth within the same national-origin minority, such as cultural practices or aspirations, and neighborhood sorting related to family background (Hällsten, Szulkin and Sarnecki 2013). To address such issues, previous studies has made progress using a strategy where data on multiple national-origin groups distributed across a large number of neighborhood contexts to provide sufficient within-neighborhood variation in local ethnic environment (Bertrand et al. 2000; Bygren and Szulkin 2010; Markussen and Røed 2015; Åslund et al. 2011). Progress has been made in previous studies that compare immigrant youth from different national-origin groups who grew up in the same neighborhood to isolate the group-specific influence of coethnics on educational outcomes from other confounding factors (Bygren and Szulkin 2010; Åslund et al. 2011). In particular, Åslund et al. (2011) also exploit a placement policy for newly arrived refugee families as a source of quasi-experimental exogenous variation in immigrant youth's neighborhood context.

\section{THE NORWEGIAN CONTEXT}

The empirical focus of the study is on immigrant youth who grew up in Norway during the 1990s and 2000s. The Norwegian case is interesting due to the combined features of strong welfare-state institutions and an ethnically diverse immigrant population. Over the past few decades, immigration to Norway has been representative of broader trends in Western Europe (Dustmann and Frattini 2013). Starting in the late 1960s, Norway first experienced labor migration - from countries such as Pakistan and Turkey — and, starting in the late 1970s, the main inflow constituted refugee populations arriving from recent conflict areas - such as Vietnam, 
Chile, Sri Lanka, and Iran (1980s), the Balkans (early 1990s), and Iraq and Somalia (late 1990s) — alongside family reunification for kin of earlier arrivals (Brochmann and Kjeldstadli 2008). By 2020, immigrants and their local-born descendants constituted $17.3 \%$ of the total Norwegian population (Statistics Norway 2019) — which is comparable to European countries such as Sweden, Denmark, Germany, France, and the United Kingdom (OECD 2017). Immigrants and their descendants are widely dispersed across geographic regions in Norway, but many live in capital of Oslo, where they currently make up one-third of the population and non-European minorities make up the majority of residents in many less-advantaged residential areas (Kornstad, Skjerpen and Stambøl 2018; Nordvik and Hedman 2018; Wessel et al. 2017).

Norway stands out in comparative perspective due to strong welfare-state institutions, low economic inequality, and low child poverty among natives (OECD 2015; UNICEF 2016). Nonetheless, immigrant minorities of non-European origin often experience low employment rates and a high prevalence of (child) poverty (Bratsberg, Raaum and Røed 2014; Galloway et al. 2015). Despite disadvantaged childhood origins, members of the second generation generally often experience upward mobility in terms of education and labor market outcomes when compared to their parents and their same-age native Norwegian peers (Bratsberg, Raaum and Røed 2012; Friberg 2019a; Hermansen 2016), but immigrant youth in several national-origin groups remain overrepresented in official crime statistics (Andersen, Holtsmark and Mohn 2017; Bratsberg et al. 2012; Hermansen 2016; Skardhamar, Aaltonen and Lehti 2014). Moreover, prior research has found that the effects of immigrant concentration in schools on both majority and minority students' outcomes are modest once sorting is adequately addressed (Hermansen and Birkelund 2015) and spatial variation in children's life chances seems to be comparatively low in Norway (Hermansen, Borgen and Mastekaasa 2020). Overall, the mechanisms operating inside co-ethnic immigrant communities and local neighborhood settings are 
likely to be of a general character, although Norway's welfare-state context may provide a conservative case in terms of the magnitude of ethnic enclave effects.

\section{DATA AND METHODS}

I use matched data on individuals and their neighborhoods of residence from Norwegian administrative registries, which provide population-wide, spatially nested records for the years 1990-2014. A system of personal identifiers enables the linkage of annually updated information from different administrative registries, including immigrant youth's criminal records and educational attainment, parental background, and measures of neighborhood environment. For the current purposes, I restrict the sample all individuals with two foreignborn parents, plus foreign-born grandparents (if registered), who themselves were either born in Norway or immigrated up to age 12, in the birth cohorts 1977-1993 and who were current residents at age 16. Thus, the sample of immigrant youth comprise both Norwegian-born members of the second-generation and childhood immigrants. Individuals with mixed ancestry (i.e., one foreign-born and one native-born parent) are not included. Finally, a small number of individuals with no information on education and crime, neighborhood location, or other key varibales were also excluded. Overall, this yields a study sample of 43,891 immigrant youth who are nested across 1,550 neighborhoods and 155 national-origin groups. Table 1 provides descriptive statistics on key variables used in the empirical analysis, while Table 2 provides information on key characteristics for the largest national ancestry groups in the study sample.

\section{< Table 1 about here >}

< Table 2 about here > 


\section{Measurement of Variables}

Adolescent crime.-To measure criminal behavior, I use use an indicator of whether the individual was ever charged for a felony between the ages of 16 and 21 (yes $=1$, no $=0$ ). Information on charges from official Norwegian crime statistics is obtained from police data, where a charge refers to investigated offenses where the person in question was the prime suspect for the recorded crime when the criminal investigation was considered solved and the case was closed by the formal report filed by the police (Lyngstad and Skardhamar 2011). ${ }^{1}$ I focus on felonies, which are crimes considered serious offenses in the Norwegian penal code (i.e., often punishable acts that carry a sentence of at least three months of imprisonment) in contrast to misdemeanors, which are largely composed of shoplifting, less-serious assaults and drunk driving, and minor larceny. The police data are highly detailed, which makes it possible to further distinguish between subcategories of felonies (e.g., theft, violence, and drug-related crimes).

Educational attainment.-Early school leaving is measured using an indicator of whether the child had completed upper-secondary education by age 21 (yes $=1$, no $=0$ ). The statutory duration of upper-secondary education in Norway is three to four years, depending on academic or vocational tracks, respectively, and individuals usually graduate from upper secondary at age 19 or 20 years. Upper-secondary education is a prerequisite for continuation into postsecondary education and upper-secondary diplomas have high labor-market returns among both children of immigrants and native-born parents (Hermansen 2013).

\footnotetext{
${ }^{1}$ Note that the term "charges" is here used with a different meaning than in the strict legal sense. Suspects are recorded in the charge data regardless of whether they were convicted, which should be seen as an advantage as a fair number of cases do not end in a conviction. Importantly, persons who were arrested and charged in an early stage of a police investigation but subequently released and no longer considered a suspect in the case will not be included in the charge data.
} 
Academic achievement.-I use information on students' grade point average (GPA) at the end of compulsory education to measure academic achievement. GPA measures the weighted sum of the student's teacher-assigned grades in eleven subjects and selected exam grades, and varies between 11 and 66. GPA is the main admission criteria to upper-secondary schools. GPA is used in $z$-standardized form (mean $=0$, std. dev. = 1). This variable is only available for cohorts graduating from lower secondary school in 2001 or later, and thus only available for a subsample in our data $(n=27,728)$.

Ethnic origin.-Ethnicity is defined on the basis of country of origin, which I rely on both to capture indivdual ethnic origin and to construct group-specific measures of ethnic neighborhood environment described below. In Norway, like in many other European countries, ethnicity is nonetheless largely seen as a reflection of the country of origin of one's family (Verkuyten 2004). However, the use of 'ethnic origin' is not entirely precise, since we only know the country of origin of the respondents' parents (and not their skin tone, religious affiliation, language, or the like). Further, it should be noted that subnational (ethnic) affinities are likely to exist (e.g., Aradhya et al. 2017) although these are not captured in these administrative data. Acknowledging these limitations, individuals' ethnic origin is measured using country of origin and this refers to the country where their parents were born, regardless of whether they themselves were born in Norway or arrived during childhood. In the few cases where country of birth differs between the immigrant paretns, the mother's country of birth is used. Using this classification, there are 155 different nationalities represented in the sample and the ten largest of these national minority groups are immigrant youth of Pakistani, Vietnamese, Turkish, Bosnia-Herzegovinian, Iraqi, Iranian, Kosovar, Somali, Chilean, and Sri Lankese national ancestry (cf. Table 2).

Ethnic neighborhood environment in adolescence.-Local ethnic enviroment is measured during early adolescence, which constitutes a developmental stage when peer relationships are 
particularly important and social networks are closely tied to school and neighborhood contexts (Brown and Larson 2009). Neighborhood contexts are captured using using information on the geographic area identifiers recorded per January 1 annually since 1990 (Statistics Norway 1999), which corresponds to Statistics Norway's geographical unit 'statistical tracts' (referred to as 'delområder' in Norwegian). These geographical units are designed to cover contiguous neighborhoods whose residents would naturally interact through common services, such as local schools and shopping center facilities. Norway is divided into about 1,457 statistical tracts and these are, on average, made up of about 3,100 residents.

Ethnic neighborhood environment is measured using information on the educational composition of (1) co-ethnic immigrant neighbors from the same origin country, (2) immigrant neighbors from other origin countries, and (3) native majority neighbors. For each individual's neighborhood, I measure the annual fraction of residents with completed upper-secondary education among all adult individuals (aged 18 through 67 years) from the same country of origin $(0=$ none, $1=$ all $)$, excluding information on each child's parents, and corresponding measures for the educational composition of all other adult immigrants from different countries of origin $(0=$ none, $1=$ all $)$ and native majority residents $(0=$ none, $1=$ all $)$. Then, $I$ compute the mean of these measures across the age span 13 through 16 for each immigrant youth. To measure the size of the coethnic community, I create corresponding measures of the mean number of coethnics living in the neighborhood when the individual was between 13 and 16 . These measures are then $\mathrm{z}$-standardized in the emprical analysis $($ mean $=0$, std. dev. $=1)$. A key feature of these variables - in partcular is that they capture dimensions of the local ethnic environment that vary substantively between members of different national-origin minorities living in the same neighborhood. To capture the influence of all stable neighborhood 
characteristics that are shared among neighboring youth, I include neighborhood fixed effects referring the neighborhood of residence during adolescence. ${ }^{2}$

Background covariates.-The data has information on several theoretically relevant and well-measured background characteristics that allow me to control for factors that may confound the relationship between ethnic neighborhood environment and later-life outcomes. Immigrant generation and age at arrival is measured by a set of dummy variables differentiating between individuals born in Norway, the foreign-born who arrived before school-starting age at seven, and the foreign-born who arrived between ages 7 and 12. I control for child gender, whether or not the child was the firstborn child of his or her mother, the number of maternal siblings, the mother's age at the child's birth and birth cohort dummies. Family structure is measured using an an indicator of whether the youth lived in an intact or reconstituted family at age 16 (i.e., in a household with two adults that were married or had common children).

Parents' socio-economic resources are measured using several indicators. Parental education is measured using information on the parent with the highest educational qualifications when the child was 16 years old. I distinguish between five levels of educational qualifications, as well as a separate category for those children with no registered parental education. Parental earnings is a composite measure of parents' pre-tax annual wages and income from self-employment. I start by averaging each parent's pre-tax annual earnings over the years the child was aged 13-16 years. Then, I summarize the mother's and the father's average earnings for this period and finally take the natural logarithm of this sum. To measure parents' labor-market attachment, I use the basic amount threshold of the Norwegian Social Insurance Scheme (used

\footnotetext{
${ }^{2}$ For individuals who move between different neighborhood during the measurement period (ages 13 through 16), the fixed effect will refer to the first observed neighborhood location (i.e., at age 13).
} 
to define labor-market status, determining eligibility for unemployment benefits as well as disability and old-age pension). In 2014, on basic amount (b.a.) was about 9,500 USD. ${ }^{3}$ I include separate indicators of stable employment for the mother and the father, based on whether they had average annual earnings above one b.a. in this period. Parents' social welfare indicates whether the parents in sum received means-tested social welfare transfers above the monthly b.a. rate (about 790 USD in 2014) in the year the child turned 16, while parental unemployment indicates whether at least one parent received unemployment benefits above the same threshold in the same year. Finally, parental years since migration measures the number of years the earliest arriving parent had lived in Norway when the child was 16 years old.

\section{Estimation Strategy}

The aim is to estimate the causal effect of ethnic neighborhood environment on immigrant youth. Specifically, I ask whether growing up among better-educated coethnic neighbors is related to better educational outcomes and less adolescent crime (enclave composition hypothesis), whether coethnic neighbors matter more than neighboring immigrants from other origin countries (ethnic boundary hypothesis), and whether coethnic neighbors' educational resources matter more in larger communities (group size hypothesis). However, methodological difficulties relates to the problem of bias from endogenous neighborhood choice and the nonrandom sorting of residents across residential areas, meaning that unobserved characteristics of immigrant youth and their families may influence both their later-life outcomes and their ethnic neighborhood environment during adolescence. Moreover, it is important to disentangle the influence of the group-specific ethnic environment from broader neighborhood effects shared by all neighboring youth (cf. Manski’s [1993] “correlated effects”). Immigrant-dense areas, for

\footnotetext{
${ }^{3}$ This was calculated using the purchasing power parities (PPP) conversion rates of the Organization for Economic Co-operation and Development (OECD), where 1 USD = 9.311 NOK in 2014.
} 
example, often have schools of low quality and access to fewer qualified teachers (Hanushek, Kain and Rivkin 2004; Schwartz and Stiefel 2011). Finally, members of different immigrantorigin ethnic minorities are also likely to differ along group-specific dimensions (e.g., cultural norms or exposure to ethnic discrimination) that may affect where they live and individual outcomes (Bertrand et al. 2000).

To handle these issues, I rely on an identification strategy that exploits within-neighborhood variation in the local composition of co-ethnic and other immigrant neighbors for members of different minority groups (Bertrand et al. 2000; Bygren and Szulkin 2010; Cutler et al. 2008). While the data allow me to control for a broad range of well-measured characteristics of the immigrant youth and their parents, their key advantage lies in the panel structure that identifies all residents from different national origins within the same area. This enables me to reduce bias from unobserved variables shared among members of the same immigrant minority and residents of the same neighborhood using fixed-effects models. I specify these models as

$$
Y_{i j k}=\alpha_{j}+\delta_{k}+\gamma \bar{C}_{i j k}+\vartheta \bar{I}_{i j k}+\mu \bar{N}_{i j k}+\theta \boldsymbol{X}_{i j k}+\varepsilon_{i j k}
$$

where $Y_{i j k}$ is the relevant outcome and the indices $i, j$, and $k$ refer to individuals, country of origin, and neighborhoods, respectively. The model includes country-of-origin fixed effects, $\alpha_{j}$, and neigborhood fixed effects, $\delta_{k}$, while $\bar{C}_{i j k}$ refers to the educational composition of coethnic neighbors and $\bar{I}_{i j k}$ and $\bar{N}_{i j k}$ refers to the educational composition among immigrant neighbors from other origin countries and native neighbors, respectively, $\boldsymbol{X}_{i j k}$ is the set of covariates of individual background characteristics, and $\varepsilon_{i j k}$ is a indvidual-specific error term.

These neighborhood fixed-effets models rely on within-neighborhood variation to assess how group-specific variation in the composition of educational resources among coethnic neighbors is related to immigrant youth's outcomes, while the inclusion of countryof-origin fixed effects will absorb all factors shared among youth from the same country of 
origin. The coefficient of primary is interest is the effect of coethnics' educational resources, which is compared to the coefficients capturing the corresponding effect of other immigrant and native neighbors' educational resources. To test the group size hypothesis, I next include the measure of number of coethnic neighbors and an interact term between this and the educational resources among coethnic neighbors. Thus, I estimate he joint effect of the educational resouces and size of the local coethnic community. As outlined above, the assumption here is that the intensity of local interaction and the social influence exerted is amplified in larger coethnic communities.

Although these analytic steps are taken to enhance confidence in a causal interpretation of the results, they do not establish causality and should interpreted with a given caveats. Specifically, the models do not capture the overall neighborhood effect, as the neighborhood fixed effect will absorb all stable characteristics shared between neighbors. Instead, the estimated coefficients captures the influence of differential exposure to local environment of neighboring coethnics and immigrants from other origin countries. Yet, the fixed effects may also absorb factors related to the causal effects of interest and thus yielding overly conservative estimates of the true effect local ethnic environments. By contrast, there is also a remaining risk of upward bias from unobserved neighborhood sorting between immigrant families from the same national-origin group. If immigrant families sort into a given neighborhood based on the specific profile of the local coethnic neighborhood community, the fixed effects regressions may not fully capture endogenous sorting based on unobserved traits (e.g., parental aspirations for their children) that are uncorrelated with the observed background covariates. 


\section{RESULTS}

Table 2 reports how immigrant youth from the largest national-origin groups have fared in terms upper-secondary completion, average grade achievement, and adolescent criminal behavior, as well as the average education among their coethnic neighbors, immigrant neighbors from other countries of origin, and native neighbors during adolescence. Several nationalorigin groups, such as Vietnam, Bosnia-Hercegovina, Sri Lanka, India, and Poland, fare relatively well both in terms of education and crime, while other origin groups, such as Pakistan, Turkey, Iraq, Iran, Kosovo, Somalia, Chile, and Morocco, complete less education, lower grade achievement, and higher rates of adolescent crime. Table 2 also reveals considerable variation in the educational composition of among co-ethnic and other immigrant neighbors across the different origin groups.

Figure 1 shows the relation between the share of high-educated coethnics relative to the corresponding share among immigrant neighbors from other origin countries (panel A) and native majority neighbors (panel B). The correlations at the individual level between these neighborhood characteristics is relatively modest, with $r=0.16$ for both other immigrant neighbors and native neighbors. This implies that these neighborhood dimensions are not highly collinear, but represent relatively unique neighborhood contexts for immigrant youth of different national origins. Moreover, the individual-level bivariate correlations between share of high-educated coethnic neighbors is considerably stronger for upper-secondary completion $(r$ $=0.12)$, average grade achievement $(r=0.18)$, and adolescent crime $(r=-0.06)$ compared to the corresponding correlations for immigrant neighbors from other origin countries and native neighbors (cf. the Pearson's correlation matrix in Table 3). This suggests that the educational resources of coethnic neighbors is more important for immigrant youth than that of local immigrants from other origin countries and member of the native majority population.

\section{< Figure 1 about here >}




\section{< Table 3 about here >}

Figure 2 shows how immigrant youth's adolescent crime and educational outcomes are related to their coethnic neighbors' educational resources and whether this relationship varies with the number of coethnics present in the neighborhood. Each scatterplot reports the mean outcomes among immigrant youth found in neighborhood environments with varying shares of high-educated coethnics for bins for individuals with different numbers of coethnic neighbors (in five-person intervals, cf. figure note). The plots reveal two relatively clear patterns: first, immigrant youth's outcomes are associated with the educational resources among their coethnics and, second, this link is stronger among immigrant youth growing up in areas with more coethnics neighbors.

\section{< Figure 2 about here >}

\section{Ethnic Neighborhood Environment and Immigrant Youth's Education and Crime}

Table 4 presents the main results from linear regression models predicting upper-secondary completion (panel A), grade achievement (panel B), and adolescent crime (panel C) among immigrant youth. In each panel, column 1 shows the linear relationship between coethnics and other immigrant neighbors' educational resources while only controlling for birth cohort and municipality fixed effects. Next, column 2 introduces controls for the full set of observed background characteristics and the country-of-origin fixed effects. This are the models of central theoretical interest, as they allow me to test the enclave composition and ethnic boundary hypotheses while strongly reducing the risk for bias caused by unobserved heterogeneity across neighborhoods and their different between their residents. Finally, column 3 tests the group size hypothesis by introducing the measure of local coethnic group size and interacting this with the average educational resources of coethnics. For the binary outcomes, I report marginal 
effects (probability changes) estimated using linear probability models. In these models, the probability of a given outcome $(y=1)$ is assumed to be a linear function of the set of predictors (Wooldridge 2010). The full set of estimated coefficients for the background covariates are reported in Appendix Table A1.

\section{< Table 4 about here >}

In column 1, the coefficient of the proportion high-educated coethnics indicates that a ten percentage-point increase in this share is related to a 0.85 percentage-point decline in the risk of committing a felony (panel A), a 2.73 percentage-point higher likelihood of completing upper secondary education (panel B), and a 0.085 standard-deviation increase in GPA (panel C). In contrast, the corresponding estimates for the proportion of high-educated other immigrants shows that a ten percentage-point increase in this share is related to a 0.83 percentage-point reduction in the likelihood of adolescent crime, a 2.15 percentage-point increase in upper-secondary completion, a 0.033 standard-deviation increase in GPA. For native neighbors, there is no association for adolescent crime, while a ten percent increase in the share of high-educated natives is related to a 0.74 reduction in the likelihood of completing upper-secondary education and a 0.050 standard-deviation reduction in GPA.

To address neighborhood sorting and unobserved heterogeneity across immigrant minorities, column 2 adjusts for observed background covariates and the country-of-origin fixed effects. The coefficients for coethnics' education indicated that a ten percentage-point increase in the high-educated share is related to a 0.34 percentage-point lower risk of engaging in adolescent crime (panel C), a 0.75 percentage-point higher likelihood of completing upper-secondary education (panel A), and a 0.023 standard-deviation increase in GPA (panel B). All of the estimated coefficients for other immigrant and native neighbors' education are substantially smaller in magnitude and fails to reach statistical significance at conventional levels. For all outcomes, these results suggest that coethnic neighbors' educational resources are more 
strongly associated with immigrant youth's outcomes compared to the average education among other immigrant neighbors. Overall, this provides support to the enclave composition and ethnic boundary hypotheses.

Finally, the models in column 3 test the group size hypothesis by examining whether the influence of coethnics' education matter more among those with larger coethnic communities in their neighborhoods of residence. For all outcomes, the estimated coefficients for the interaction term are in the expected direction (i.e., positive for the educational outcomes and negative for crime), but none reach statistical significance at the $p<0.05$ level. Nonetheless, I present the predicted relationships based on these coefficients graphically in Figure 4. For all outcomes, the predicted patterns indicates that coethnic neighbors' educational resources on the immigrant youth's outcomes matter slightly more in larger communities. However, when selection is addressed, this interaction effect is not strong in substantive terms and fails to reach statistical significance at conventional levels. Thus, the local group size hypothesis does not receive strong support.

\section{$<$ Figure 4 about here >}

Overall, these results are in line with the theoretical expectations and show how educational resources embedded in local coethnic communities shape the assimilation trajectories of immigrant youth in Norwegian neighborhoods. However, while the results provides some support that the influence of coethnic resources is stronger in larger communities, this interaction effect is not strong. In the following, I present estimated effects on subcategories of adolescent crime, explore the mediating role of grade achievement for later outcomes, and conduct robustness analyses. 
Next, I assess whether the effect of coethnics' educational resources varies by subcategories of adolescent crime. Table 5 presents separate effects for felonies related to damages, drugs, sexual offenses, violence, property theft, economic crimes, traffic offenses, and other crimes. I find the strongest effect on felonies related to violence, followed by property theft, traffic offenses, and other crimes. However, the estimated effect of immigrant neighbors' education on property crimes is small. Overall, this implies that variation in coethnics' educational resources is related a broad range of subcategories of adolescent crime among immigrant youth.

\section{< Table 5 about here >}

\section{Coethnic Neighbors' Education and the Role of Grade Achievement for Later-Life Outcomes}

An important question is whether the effect of ethnic neighborhood environment on early adult outcomes reflects differences in school success at the end of compulsory education. To explore the mediating role of early school achievement, Table 6 presents models where I estimate the effect of coethnics' educational resources on adolescent crime (panel A) and upper-secondary education (panel B) before and after controls for average grades. As information on GPA is only available for cohorts who completed lower-secondary education in 2001 or later, I first present baseline estimates without control for school grades for the full sample and this restricted sample. Then, I present the estimated coefficients after controlling for average grade achievement.

\section{< Table 6 about here >}

Table 6 shows that the estimated coefficients in the baseline model is very similar in the full and the restricted sample for both upper-secondary completion and adolescent crime. When controlling for GPA, the estimated coefficient for the effect of coethnics' educational resources 
on adolescent crime (panel A) is cut in half and rendered statistically non-significant. The corresponding effect on upper-secondary completion (panel B) is reduced by about two thirds and is also no longer statistically significant. These results suggest that a substantial part of the effects of coethnics' educational resources operates via school success in early adolescence.

\section{Robustness Analyses}

Table 7 reports results from two robustness analyses. First, one concern is that variation in small groups of coethnic neighbors may reflect the presence of adult members in extended kin networks (e.g., grandparents or aunts and uncles) since some immigrant youth grow up in areas with few coethnics. To address this, Table 7 explores whether estimated effects of coethnics' educational resources are robust when constraining the sample to immigrant youth who grew up in neighborhoods with larger groups of local coethnic neighbors. To achieve this, I compare the estimates from the full sample to models where the sample is constrained immigrant youth who had at least 5, 10, 25 or 50 coethnic neighbors. ${ }^{4}$ The results show that the estimated coefficients for the share of high-educated coethnics are relatively stable when we constrain the sample to a minimum number for local coethnics present. Overall, the coefficients are comparable in size, or even larger, when constraining the sample to immigrant youth with large coethnic networks. As such, this implies that the estimated effects from the full sample models do not reflect variation within small coethnic networks.

\section{< Table 7 about here >}

Second, following Bygren and Szulkin (2010), I also re-estimated the results separately for immigrant youth who lived in the same neighborhood during the observed period and those

\footnotetext{
${ }^{4}$ Note that we exclude a substantial share of our sample in these models, as for example about $27 \%$ of the immigrant youth grew up in local areas with less than 10 coethnic neighbors.
} 
who experienced at least one residential relocation as a further robustness analyses. The results are relatively comparable for the residential stayers and movers across all outcomes, although the coefficient for movers on adolescent crime does not reach statistical significance at conventional levels. Thus, the coefficients do not seem to be identified primarily from neighborhood variation in coethnic neighbors' educational resources induced by residential mobility.

\section{DISCUSSION}

Using rich Norwegian administrative data, this study has addressed the association between ethnic neighborhood environment and immigrant youth's adolescent criminal behavior and educational careers. By creating detailed measures of the educational resources among adult coethnic, other immigrant, and native neighbors during early adolescence, I was able to link this to longitudinal individual data on immigrant youth's later outcomes. To address confounding from shared contextual factors and neighborhood sorting, I estimate fixed-effects regressions that exploit within-neighborhood variation in local ethnic environment among immigrant youth from different national origins while also adjusting for a broad range of observed socioeconomic resources in the family of origin and unobserved heterogeneities across immigrant groups. By focusing on how local educational resources found within ethnic enclaves matter for adolescent crime and early school leaving, this study provides a broader assessment of how adolescent ethnic environments shape assimilation outcomes that may constitute key tuning points in the life course.

The findings reveal that neighborhood-level exposure to better-educated coethnics during adolescence is related to lower risks of engaging in criminal behavior during late adolescence, higher likelihoods of completing upper-secondary education, and better grade achievements at the end of compulsory education. While extending the current literature by including a focus 
on adolescent crime, the findings align well with prior studies showing that growing up alongside resourceful coethnic neighbors fosters educational success among immigrant youth (Bygren and Szulkin 2010; Fleischmann et al. 2013; Kroneberg 2008; Åslund et al. 2011). As shown earlier by Bygren and Szulkin (2010), I also found some support that coethnic neighbors' educational resources matter more in areas with larger concentrations of immigrants from the same origin country. However, this relationship was relatively modest and failed to reach statistical significance once confounding factors were taking to account. Moreover, I found spatial proximity to better-educated neighboring immigrants from other origin countries and members of the native majority to be less consequential for both crime and education. This suggests that social interaction in the local area is confined by ethnic boundaries within different immigrant minorities, which is also in line with similar gradients of ethnic relatedness found in earlier research (Fleischmann et al. 2013; Markussen and Røed 2015; Åslund et al. 2011). On the whole, these findings provides support to theoretical arguments (Borjas 1995; Portes and Zhou 1993) claiming that local context of coethnic neighbors and the educational resources found in these social networks shape the future life chances and structural incorporation of immigrant youth.

While it is difficult to identify the precise mechanisms through which the influence of coethnic neighbors arise, I find that academic achievements at the end of compulsory education accounts for about half (adolescent crime) and two-thirds (upper-secondary completion) of the effect of coethnic neighbors' educational resources. This suggests that early skill formation is central to understanding the influence of coethnic neighbors on immigrant youth's later risk of early school leaving and criminal behavior. While the analysis is less informative on mechanisms that link variation in coethnic neighbors' resources to immigrant youth's delinquent behavior and educational careers, this limitation is shared with prior work where conclusions on social influence in local immigrant communities are drawn from administrative data (Bygren 
and Szulkin 2010; Markussen and Røed 2015; Åslund et al. 2011). With improved access to sociometric data (Kruse and Kroneberg 2019; Leszczensky and Pink 2019; Smith et al. 2016), future research should take advantage of more direct measures of social network structures and interaction patterns to unpack how ethnic neighborhood environments are linked to the behaviors of immigrant youth. Kroneberg (2008), for example, found a stronger effect of coethnic neighbors' educational resources on school performance among immigrant youth whose parents reported to socialize mainly with coethnics.

A key contribution of this study is assessing of how group-specific ethnic enclave effects vary across immigrant youth from different national-origin groups who grew up in the neighborhood. As neighboring immigrant youth of diverse ethnic origins be embedded in and influenced by different social networks, this relates to a recent move away from the dichotomous question of whether or not neighborhoods matters towards more nuanced questions relating to for whom and under what conditions they might be consequential (Sharkey and Faber 2014). While disentangling the group-specific social interaction effects in local immigrant communities from broader contextual effects in the neighborhood is a strength for the current purposes, it should be noted that the reported estimates do not reflect the overall 'neighborhood effect' which also involves neighborhood factors shared by all neighboring youth such as school quality or other local institutions.

One should always be cautious regarding causal interpretations of results from nonexperimental data, and this study is no exception. Although I control for unobserved heterogeneity at the level of neighborhoods and immigrant minorities, as well as a broad set of observed background characteristics, a final caveat related to group-specific neighborhood sorting should be noted. If immigrant families sort into a given neighborhood based on the profile of local residents from the same ethnic minority group, self-selection may introduce bias from unobserved traits that is specific to members of the given minority group in that area. To further rule out 
potential outstanding sources of heterogeneity, we would need a source of plausibly exogenous variation in the ethnic neighborhood environment. For instance, Åslund et al. (2011) found similar ethnic enclave effects on immigrant youth's academic achievement when exploiting quasi-random settlement patterns resulting from a placement policy for newly arrived refugee families. While this is reassuring, a fruitful avenue for future work would be to use similar approaches to study ethnic enclave effects on immigrant youth's adolescent crime and other long-term assimilation trajectories.

To what extent do ethnic enclaves promote or hinder the life chances of immigrant youth? Growing up alongside many less-educated coethnics heightens the risk of delinquent behavior and poor educational outcomes, while exposure to better-educated coethnic neighbors during adolescence has beneficial effects on immigrant youth's later-life outcomes. Moreover, the educational resources of coethnic neighbors seem to be more consequential for immigrant youth's future criminal behavior and educational careers than the local presence of immigrants from other origin countries and members of the native majority population. While the egalitarian character of Norwegian society likely provides lower-bound estimates on the role of adolescent neighborhood environments (Hermansen et al. 2020), the general character of the underlying social mechanisms behind the patterns we observe — such as social control and normative pressure, transmission of aspirations, and help with homework or access to school-related information - suggests that these findings should be of relevance to other immigrant-receiving societies.

\section{REFERENCES}

Alba, R.and N. Foner. 2015. Strangers No More: Immigration and the Challenges of Integration in North America and Western Europe. Princeton: Princeton University Press. 
Andersen, S.N., B. Holtsmark, and S.B. Mohn. 2017. "Kriminalitet blant innvandrere og norskfødte med innvandrerforeldre: En analyse av registerdata for perioden 1992-2015." Oslo/Kongsvinger: Statistics Norway.

Andersson, E.K., B. Malmberg, R. Costa, B. Sleutjes, M.J. Stonawski, and H.A.G. de Valk. 2018. "A Comparative Study of Segregation Patterns in Belgium, Denmark, the Netherlands and Sweden: Neighbourhood Concentration and Representation of NonEuropean Migrants." European Journal of Population 34(2):251-275.

Aradhya, S., F. Hedefalk, J. Helgertz, and K. Scott. 2017. "Region of Origin: Settlement Decisions of Turkish and Iranian Immigrants in Sweden, 1968-2001." Population, Space and Place 23(4):e2031.

Benner, A.D.and R. Crosnoe. 2011. "The Racial/Ethnic Composition of Elementary Schools and Young Children's Academic and Socioemotional Functioning." American Educational Research Journal 48(3):621-646.

Bertrand, M., E.F.P. Luttmer, and S. Mullainathan. 2000. "Network Effects and Welfare Cultures." The Quarterly Journal of Economics 115(3):1019-1055.

Bisin, A., E. Patacchini, T. Verdier, and Y. Zenou. 2011. "Formation and persistence of oppositional identities." European Economic Review 55(8):1046-1071.

Blau, P.M. 1977. "A Macrosociological Theory of Social Structure." American Journal of Sociology 83(1):26-54.

Borjas, G.J. 1992. "Ethnic Capital and Intergenerational Mobility." Quarterly Journal of Economics 107(1):123-150.

—. 1995. "Ethnicity, Neighborhoods, and Human-Capital Externalities." American Economic Review 85(3):365-390. 
Bratsberg, B., O. Raaum, and K. Røed. 2012. "Educating Children of Immigrants: Closing the Gap in Norwegian Schools." Nordic Economic Policy Review 3(1):211-251.

—. 2014. "Immigrants, Labour Market Performance and Social Insurance." Economic Journal 124(580):F644-F683.

Brochmann, G.and K. Kjeldstadli. 2008. A History of Immigration: The Case of Norway, 900-2000. Oslo: Universitetsforlaget.

Brown, B.B.and J. Larson. 2009. "Peer Relationships in Adolescence." in Handbook of Adolescent Psychology: John Wiley \& Sons, Inc.

Bygren, M.and R. Szulkin. 2010. "Ethnic Environment During Childhood and the Educational Attainment of Immigrant Children in Sweden." Social Forces 88(3):13051329.

Coleman, J.S. 1988. "Social Capital in the Creation of Human Capital." American Journal of Sociology 94:S95-S120.

Conger, D., A.E. Schwartz, and L. Stiefel. 2011. "The Effect of Immigrant Communities on Foreign-Born Student Achievement." International Migration Review 45(3):675-701.

Currarini, S., M.O. Jackson, and P. Pin. 2010. "Identifying the roles of race-based choice and chance in high school friendship network formation." Proceedings of the National Academy of Sciences 107(11):4857-4861.

Cutler, D.M., E.L. Glaeser, and J.L. Vigdor. 2008. "When are ghettos bad? Lessons from immigrant segregation in the United States." Journal of Urban Economics 63(3):759-774.

DiPietro, S.M.and J.M. McGloin. 2012. "Differential susceptibility? Immigrant youth and peer influence." Criminology 50(3):711-742. 
Drouhot, L.G.and V. Nee. 2019. "Assimilation and the Second Generation in Europe and America: Blending and Segregating Social Dynamics Between Immigrants and Natives." Annual Review of Sociology 45(1):177-199.

Dustmann, C.and T. Frattini. 2013. "Immigration: the European experience." Pp. 423-456 in Immigration, Poverty, and Socioeconomic Inequality, edited by D. Card and S. Raphael. New York: Russell Sage Foundation.

Feld, S.L. 1981. "The focused organization of social ties." American Journal of Sociology 86(5):1015-1035.

Fleischmann, F., P. Deboosere, K. Neels, and K. Phalet. 2013. "From Ethnic Capital to Ethnic Educational Inequality: How Family and Co-Ethnic Neighbourhood Resources Affect Second-Generation Attainment in Belgium." European Sociological Review 29(6):1239-1250.

Friberg, J.H. 2019a. "Does selective acculturation work? Cultural orientations, educational aspirations and school effort among children of immigrants in Norway." Journal of Ethnic and Migration Studies 45(15):2844-2863.

—. 2019b. Konflikt, fellesskap og forandring: Foreldreskap og sosial kontroll i innvandrede familier fra Pakistan, Somalia og Sri Lanka. Oslo: Cappelen Damm Akademisk.

Galloway, T.A., B. Gustafsson, P.J. Pedersen, and T. Österberg. 2015. "Immigrant Child Poverty: The Achilles Heel of the Scandinavian Welfare State." Pp. 185-219 in Measurement of Poverty, Deprivation, and Economic Mobility, edited by T.I. Garner and K.S. Short: Emerald Group Publishing Limited.

Georgiades, K., M.H. Boyle, and K.A. Fife. 2013. "Emotional and Behavioral Problems Among Adolescent Students: The Role of Immigrant, Racial/Ethnic Congruence and Belongingness in Schools." Journal of Youth and Adolescence 42(9):1473-1492. 
Geven, S., M. Kalmijn, and F. van Tubergen. 2016. "The ethnic composition of schools and students' problem behaviour in four European countries: the role of friends." Journal of Ethnic and Migration Studies 42(9):1473-1495.

Hall, M. 2013. "Residential Integration on the New Frontier: Immigrant Segregation in Established and New Destinations." Demography 50(5):1873-1896.

Hanushek, E.A., J.F. Kain, and S.G. Rivkin. 2004. "Why Public Schools Lose Teachers." Journal of Human Resources 39(2):326-354.

Harding, D.J., L. Gennetian, C. Winship, L. Sanbonmatsu, and J.R. Kling. 2011. "Unpacking Neighborhood Influences on Education Outcomes: Setting the Stage for Future Research." Pp. 277-296 in Whither Opportunity? Rising Inequality, Schools, and Children's Life Chances, edited by G.J. Duncan and R.J. Murnane. New York: Russell Sage Foundation.

Haynie, D.L., E. Silver, and B. Teasdale. 2006. "Neighborhood Characteristics, Peer Networks, and Adolescent Violence." Journal of Quantitative Criminology 22(2):147-169.

Heath, A.F. 2007. "Crossnational Patterns and Processes of Ethnic Disadvantage." Pp. 639695 in Unequal Chances: Ethnic Minorities in Western Labour Markets, edited by A.F. Heath and S.Y. Cheung. Oxford: Oxford University Press/The British Academy.

Hermansen, A.S. 2013. "Occupational Attainment among Children of Immigrants in Norway: Bottlenecks into Employment_Equal Access to Advantaged Positions?" European Sociological Review 29(3):517-534.

—. 2016. "Moving Up or Falling Behind? Intergenerational Socioeconomic Transmission among Children of Immigrants in Norway." European Sociological Review 32(5):675-689.

Hermansen, A.S.and G.E. Birkelund. 2015. "The Impact of Immigrant Classmates on Educational Outcomes." Social Forces 94(2):615-646. 
Hermansen, A.S., N.T. Borgen, and A. Mastekaasa. 2020. "Long-term trends in adult socioeconomic resemblance between former schoolmates and neighbouring children." European Sociological Review 36(3):366-380.

Hällsten, M., R. Szulkin, and J. Sarnecki. 2013. "Crime as a Price of Inequality? The Gap in Registered Crime between Childhood Immigrants, Children of Immigrants and Children of Native Swedes." British Journal of Criminology 53(3):456-481.

Jencks, C.and S.E. Mayer. 1990. "The Social Consequences of Growing Up in a Poor Neighborhood." in Inner-City Poverty in the United States, edited by L. Lynn and M. McGreary. Washingtion, DC: National Academic Press.

Kalter, F., J.O. Jonsson, F.v. Tubergen, and A. Heath. 2018. Growing up in diverse societies: the integration of children of immigrants in England, Germany, the Netherlands and Sweden. Oxford: Oxford University Press.

Kasinitz, P., J. Mollenkopf, M. Waters, and J. Holdaway. 2008. Inheriting the City: The Children of Immigrants Come of Age New York: Russell Sage Foundation.

Kornstad, T., T. Skjerpen, and L.S. Stambøl. 2018. "Utviklingen i bostedssegregering i utvalgte store og sentrale kommuner etter 2005." Oslo/Kongsvinger: Statistics Norway.

Kroneberg, C. 2008. "Ethnic Communities and School Performance among the New Second Generation in the United States: Testing the Theory of Segmented Assimilation." Annals of the American Academy of Political and Social Science 620(1):138-160.

Kruse, H.and C. Kroneberg. 2019. "More Than a Sorting Machine: Ethnic Boundary Making in a Stratified School System." American Journal of Sociology 125(2):431-484.

Lee, J.and M. Zhou. 2015. The Asian American Achievement Paradox. New York: Russell Sage Foundation. 
Lee, R. 2018. "How do coethnic communities matter for educational attainment? A comparative analysis of the United States and Canada." International Journal of Comparative Sociology 59(2):139-164.

Leszczensky, L.and S. Pink. 2019. "What drives ethnic homophily? A relational approach on how ethnic identification moderates preferences for same-ethnic friends." American Sociological Review 84(3):394-419.

Lewis, K. 2015. "How Networks Form: Homophily, Opportunity, and Balance." Pp. 1-14 in Emerging Trends in the Social and Behavioral Sciences, edited by R.A. Scott and S.M. Kosslyn. Hoboken, NJ: John Wiley \& Sons.

Lyngstad, T.H.and T. Skardhamar. 2011. "Nordic Register Data and Their Untapped Potential for Criminological Knowledge." Crime and Justice 40(1):613-645.

Manski, C.F. 1993. "Identification of Endogenous Social Effects: The Reflection Problem." The Review of Economic Studies 60(3):531-542.

Markussen, S.and K. Røed. 2015. "Social Insurance Networks." Journal of Human Resources 50(4):1081-1113.

McFarland, D.A., J. Moody, D. Diehl, J.A. Smith, and R.J. Thomas. 2014. "Network ecology and adolescent social structure." American Sociological Review 79(6):1088-1121.

McPherson, M., L. Smith-Lovin, and J.M. Cook. 2001. "Birds of a Feather: Homophily in Social Networks." Annual Review of Sociology 27:415-444.

Moody, J. 2001. "Race, School Integration, and Friendship Segregation in America." American Journal of Sociology 107(3):679-716.

Mouw, T.and B. Entwisle. 2006. "Residential Segregation and Interracial Friendship in Schools." American Journal of Sociology 112(2):394-441. 
Musterd, S. 2005. "Social and Ethnic Segregation in Europe: Levels, Causes, and Effects." Journal of Urban Affairs 27(3):331-348.

Nordvik, V.and L. Hedman. 2018. "Neighbourhood attainment of children of immigrants in Greater Oslo: Intergenerational inertia and the role of education." Population, Space and Place:e2192, https://doi.org/2110.1002/psp.2192.

OECD. 2015. In It Together: Why Less Inequality Benefits All. Paris: OECD.

—. 2017. International Migration Outlook. Paris: OECD.

Portes, A. 1998. "Social Capital: Its Origins and Applications in Modern Sociology." Annual Review of Sociology 24(1):1-24.

Portes, A.and D. MacLeod. 1996. "Educational Progress of Children of Immigrants: The Roles of Class, Ethnicity, and School Context." Sociology of Education 69(4):255-275.

Portes, A.and R.G. Rumbaut. 2001. Legacies: The Story of the Immigrant Second Generation. Berkeley: Russell Sage Foundation.

Portes, A.and M. Zhou. 1993. "The New Second Generation: Segmented Assimilation and Its Variants." Annals of the American Academy of Political and Social Science 530:74-96.

Sampson, R.J., J.D. Morenoff, and F. Earls. 1999. "Beyond social capital: Spatial dynamics of collective efficacy for children." American Sociological Review 64(5):633-660.

Sampson, R.J., J.D. Morenoff, and T. Gannon-Rowley. 2002. "Assessing "Neighborhood Effects": Social Processes and New Directions in Research." Annual Review of Sociology 28:443-478.

Schwartz, A.E.and L. Stiefel. 2011. "Immigrants and Inequality in Public Schools." Pp. 419442 in Whither Opportunity? Rising Inequality, Schools, and Children's Life Chances, 
edited by G.J. Duncan and R.J. Murnane. New York/Chicago: Russell Sage Foundation/Spencer Foundation.

Sharkey, P.and J.W. Faber. 2014. "Where, When, Why, and For Whom Do Residential Contexts Matter? Moving Away from the Dichotomous Understanding of Neighborhood Effects." Annual Review of Sociology 40(1):559-579.

Skardhamar, T., M. Aaltonen, and M. Lehti. 2014. "Immigrant crime in Norway and Finland." Journal of Scandinavian Studies in Criminology and Crime Prevention 15(2):107-127.

Smith, S., D.A. McFarland, F.V. Tubergen, and I. Maas. 2016. "Ethnic Composition and Friendship Segregation: Differential Effects for Adolescent Natives and Immigrants." American Journal of Sociology 121(4):1223-1272.

Statistics Norway. 1999. "Regional Classifications. A Survey of Standards in Official Statistics of Norway." Oslo/Kongsvinger: Statistics Norway.

—. 2019. Immigrants and Norwegian-Born to Immigrant Parents, January 1, 2019 [available at <http://ssb.nolen/befolkning/statistikker/innvbef > ]. Oslo/Kongsvinger: Statistics Norway.

UNICEF. 2016. Fairness for Children: A League Table of Inequality in Child Well-being in Rich Countries. Florence: UNICEF Office of Research - Innocenti.

Verkuyten, M. 2004. The Social Psychology of Ethnic Identity. London, UK: Psychology Press.

Vogel, M.and S.J. South. 2016. "Spatial dimensions of the effect of neighborhood disadvantage on delinquency." Criminology 54(3):434-458. 
Waters, M.C.and M.G. Pineau. 2015. The Integration of Immigrants into American Society. Washington, DC: The National Academies Press.

Wessel, T., R. Andersson, T. Kauppinen, and H.S. Andersen. 2017. "Spatial Integration of Immigrants in Nordic Cities: The Relevance of Spatial Assimilation Theory in a Welfare State Context." Urban Affairs Review 53(5):812-842.

Wooldridge, J.M. 2010. Econometric Analysis of Cross Section and Panel Data. Cambridge, Mass.: MIT Press.

Zhou, M.and C. Bankston. 1998. Growing up American: How Vietnamese children adapt to life in the United States. New York: Russell Sage Foundation.

Zimmerman, G.M.and S.F. Messner. 2011. "Neighborhood Context and Nonlinear Peer Effects on Adolescent Violent Crime." Criminology 49(3):873-903.

Åslund, O., P.-A. Edin, P. Fredriksson, and H. Grönqvist. 2011. "Peers, Neighborhoods, and Immigrant Student Achievement: Evidence from a Placement Policy." American Economic Journal: Applied Economics 3(2):67-95. 
(a) Coethnic vs immigrant neighbors' education

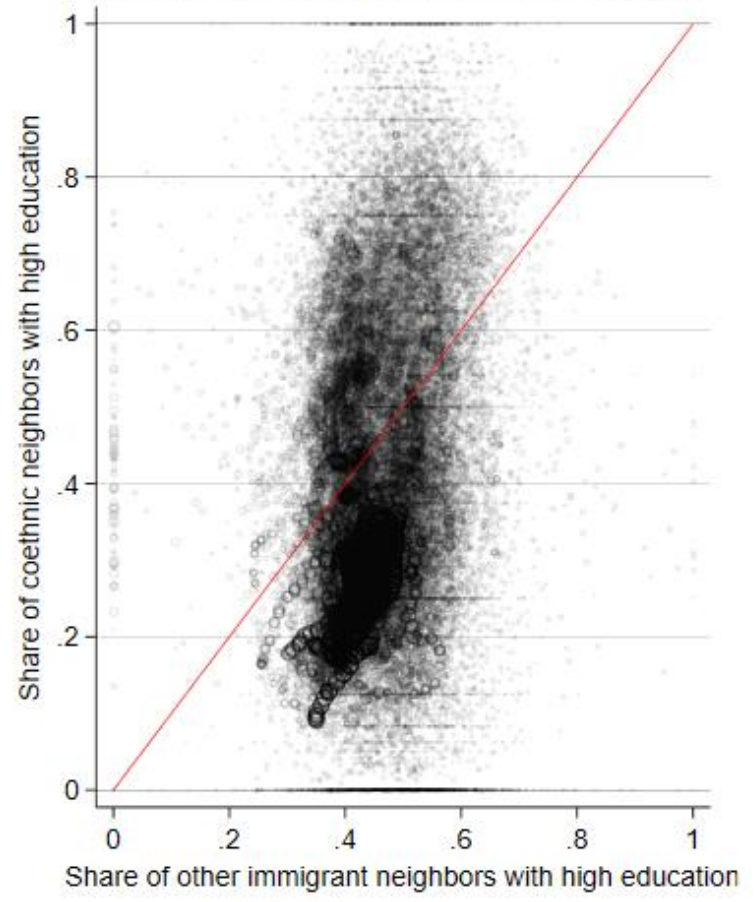

(b) Coethnic vs native neighbors' education

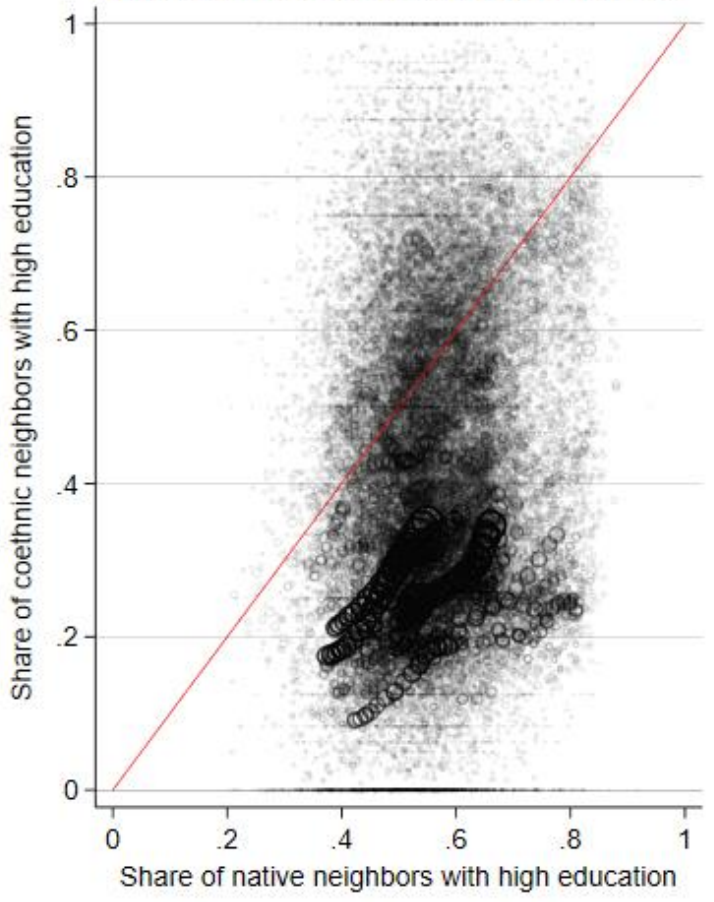

Figure 1. Relationship between the educational resources among coethnic neighbors versus other immigrant neighbors (panel A) and native neighbors (panel B).

Note: Bivariate correlations are $r=0.157$ (panel A) and $r=0.163$ (panel B). Each scatterplot circle plots the relevant characteristics of the ethnic neighborhood environment for individual immigrant youth $(\mathrm{N}=43,881)$, where the size of the circles are weighted by the number of coethnic neighbors for each individual observation. The diagonal red line refers to cases where share of neighbors with high education along the two dimensions are identical. 

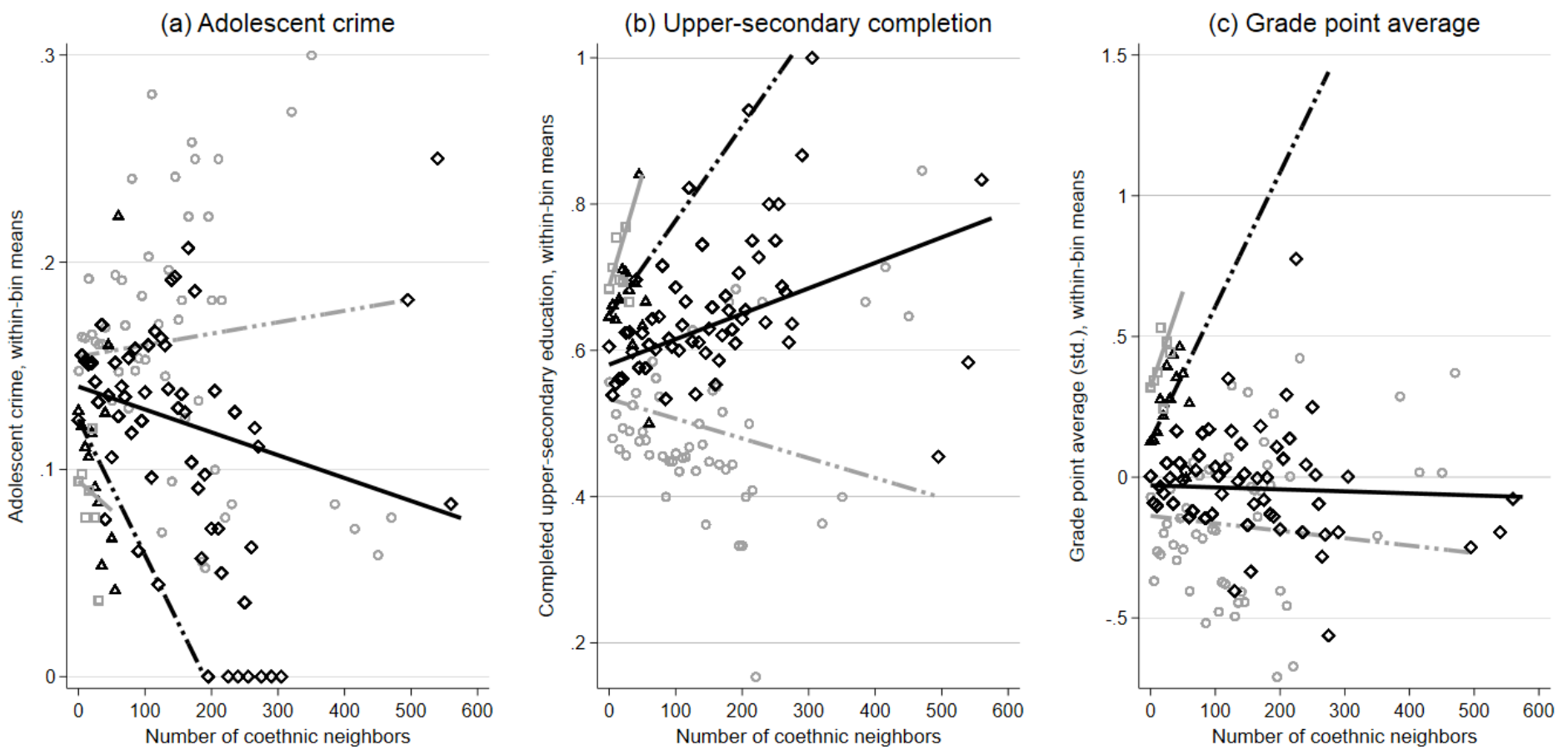

O Bins, $<.25$ high-educated _ = " " Linear fit, $<.25$ high-educated

$\diamond$ Bins, $.25-.50$ high-educated

Linear fit, .25-.50 high-educated

$\Delta$ Bins, $.50-.75$ high-educated

. - Linear fit, .50-.75 high-educated

$\square$ Bins, $>.75$ high-educated $\quad$ Linear fit, $>.75$ high-educated

Figure 2. Relationship between the number of coethnic neighbors, the share of high-educated coethnics, and immigrant youth's adolescent crime (panel A), upper-secondary completion (panel B), and grade point averages (panel C).

Note: The scatter plots in each panel depicts the immigrant youth's mean for the relevant outcome within bins of the number coethnic neighbors in five-person intervals and four levels of the share with high education among these coethnic neighbors. Linear fit slopes are based on all bins within each level of coethnics' education, while only bins with at least five immigrant youth are shown. 
(a) Adolescent crime

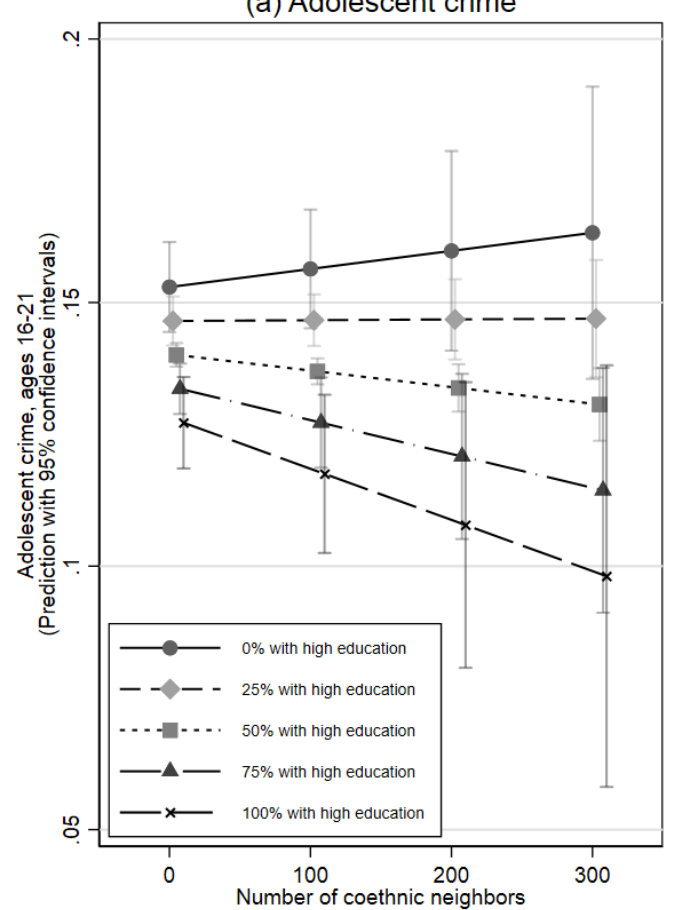

(b) Upper-secondary completion

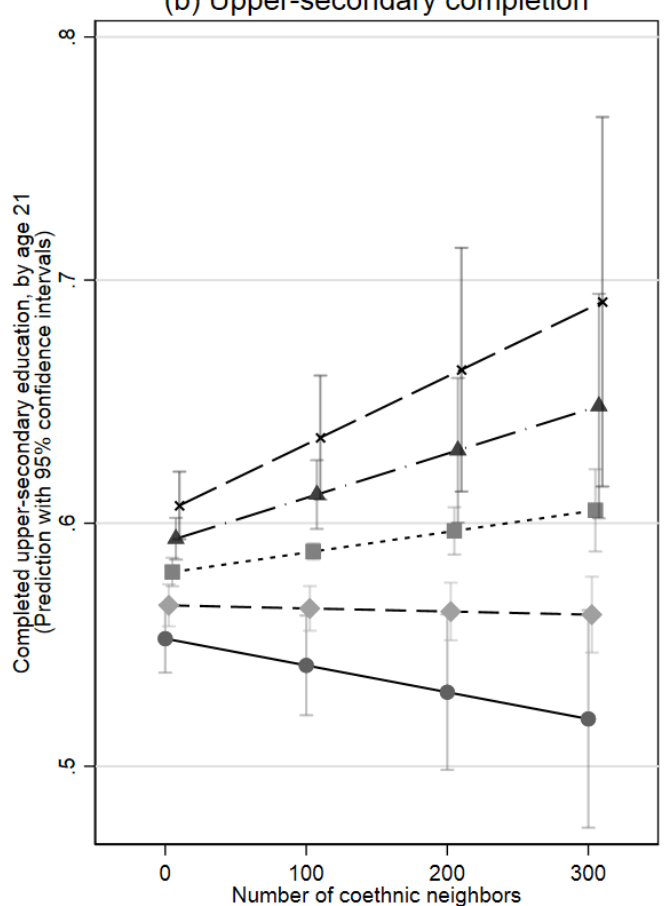

(c) Grade point average

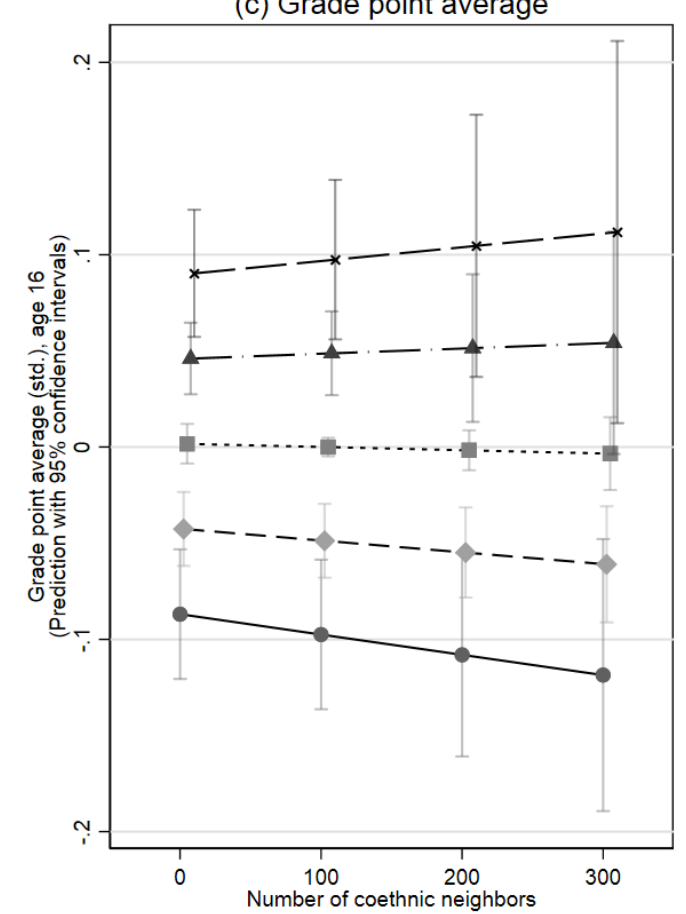

Figure 3. Estimated relationship between the number of coethnic neighbors, their educational resources, and immigrant youth's adolescent crime (panel A), upper-secondary completion (panel B), and grade point average (panel C) from OLS regressions.

Note: Estimates based on coefficients from the models in column 3, 6, and 9 in Table 3, net of neighborhood fixed effects, country-of-origin fixed effects, and background covariates. Error bars indicate 95 percent confidence intervals. 


$\begin{array}{lllll}\text { Mean } & \frac{\mathrm{SD}}{(1)} & \frac{\operatorname{Min}}{(2)} & \frac{\mathrm{Max}}{(4)} & \frac{\mathrm{N}}{(5)}\end{array}$

\section{Adolescent outcome variables}

Adolescent crime

0.133

0

43,891

Adolescent crime by subcategories

Damages
Drugs
Sexual
Violence
Property
Economic
Traffic
Other
Completion of upper-secondary education

0.017

0.058

0.003

0.062

0.072

0.007

0.042

0.057

0.586

38.06

0

$\begin{array}{lll}0 & 1\end{array}$

43,891

Grade point average

11.22

$$
0
$$

43,891

43,891

43,891

43,891

43,891

43,891

Measures of ethnic neighborhood environment

Coethnic neighbors from same origin country

Share of coethnics with high education

Number of coethnic neighbors

$\begin{array}{lllll}0.398 & 0.216 & 0 & 1 & 43,891 \\ 138.7 & 293.0 & 0 & 2,061 & 43,891 \\ 0.467 & 0.084 & 0 & 1 & 43,891 \\ 0.559 & 0.101 & 0.203 & 0.937 & 43,891\end{array}$

Immigrant neighbors from other origin countries

Share of other immigrants with high education

Native majority neighbors

Share of natives with high education

\section{Background covariates}

Born in Norway

0.423

Foreign-born, arrival ages 0-6 years

0.248

0.329

Foreign-born, arrival ages 7-12 years

0.487

Female

0.389

2.38

1986.82

0

43,891

First-born child of mother

27.18

0.783

16.7

0

43,891

43,891

43,891

Number of siblings

Birth cohort

Mother's age at birth

Intact or reconstituted family

Parents' years since migration

Parents' education

Less than upper secondary

0.333

0.201

Completed upper secondary

0.196

Postsecondary degree, short

0.083

Postsecondary degree, long

0.188

1.69

0

1

1

1

1

43,891

1

43,891

4.65

0

43,891

5.81

1977

1993

43,891

43,891

43,891

No information registered

11.20

8.8

0

45

1

60

43,891

43,891

43,891

43,891

43,891

Parents' earnings (log)

0.594

3.98

0.557

0.222

0.139

0
0
0
0
0
0.00
0
0
0
0

43,891

43,891

43,891

43,891

43,891

Parents' unemployment

Source: Author's calculations of Norwegian administrative data provided by Statistics Norway.

Note: Standard deviations are not shown for discrete variables, as the full distribution of responses is shown. Sample includes children graduating from compulsory education at ages 15-17 between 1993 and 2009. 
Table 2. Summary of mean values for key variables for immigrant youth by country of origin

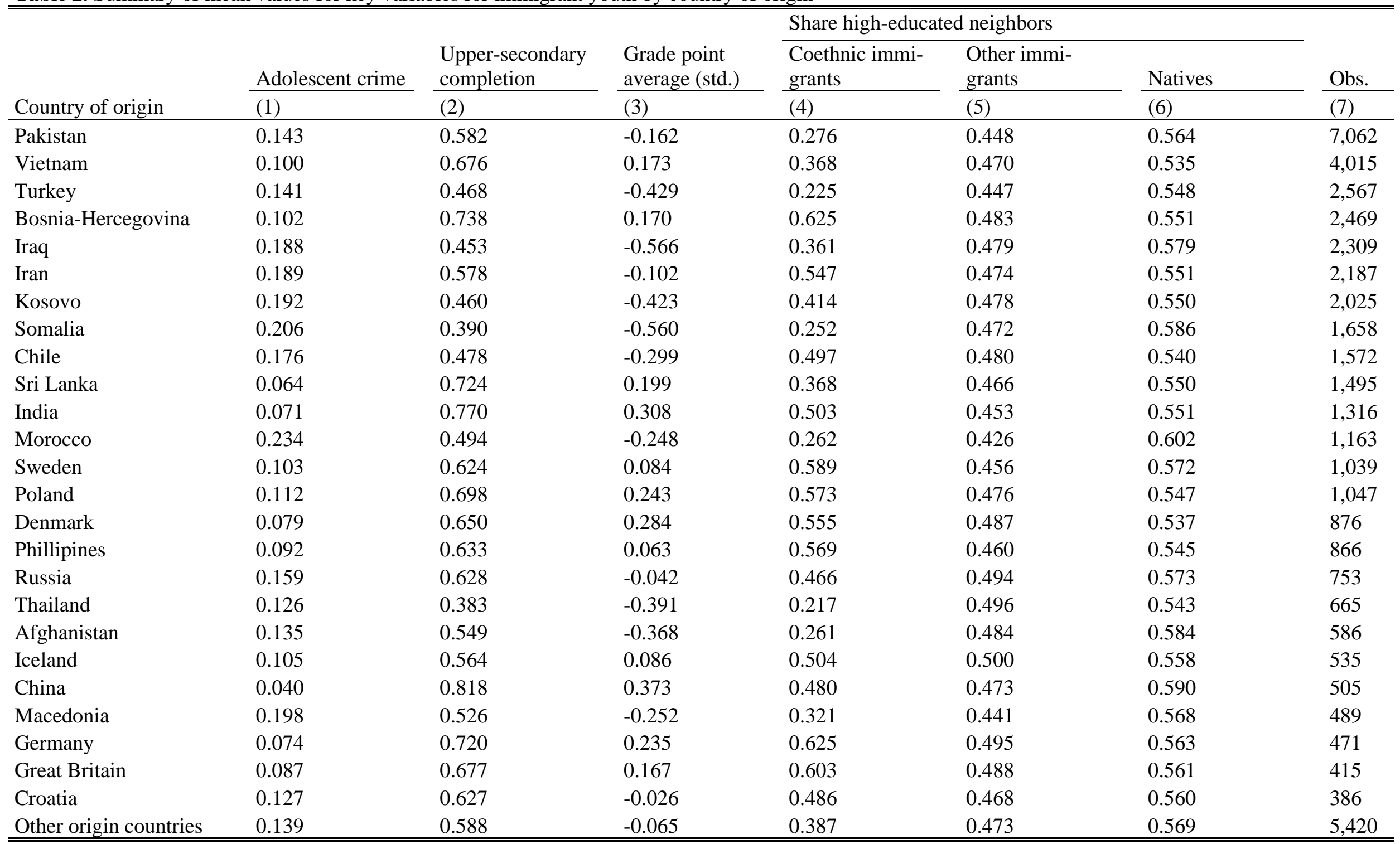

Note: Except for the number of observations, all cells report the mean value for each variable conditioned within the given country of origin. Note that the number of observations for grade achievement for each country of origin is lower than the number reported for all birth cohorts, as this variable is only available from 2001 and onwards. 
Table 3. Pearson's correlation matrix of ethnic neighborhood characteristics and immigrant youth outcomes.

\begin{tabular}{lrrrrrrr}
\hline & \multicolumn{1}{c}{ (1) } & \multicolumn{1}{c}{$(2)$} & \multicolumn{1}{c}{ (3) } & (4) & (5) & (6) & (7) \\
\hline (1) Co-ethnic neighbors' education & 1.00 & & & & & & \\
(2) Immigrant neighbors' education & 0.16 & 1.00 & & & & & \\
(3) Native neighbors' education & 0.16 & 0.38 & 1.00 & & & & \\
(4) Number of coethnic neighbors & -0.17 & -0.18 & -0.03 & 1.00 & & & \\
(5) Upper-secondary completion & 0.12 & 0.05 & 0.02 & 0.01 & 1.00 & & \\
(6) Grade point average (std.) & 0.18 & 0.03 & -0.02 & -0.01 & 0.53 & 1.00 & \\
(7) Adolescent crime, all types & -0.06 & -0.03 & -0.02 & -0.01 & -0.28 & -0.25 & 1.00 \\
\hline \hline
\end{tabular}




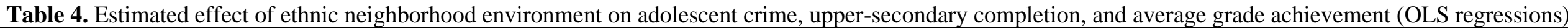

\begin{tabular}{|c|c|c|c|c|c|c|c|c|c|}
\hline & Panel A. A & lescent cri & & Panel B. L & er-seconda & completion & Panel C. G & de point ave & \\
\hline & $(1)$ & $(2)$ & $(3)$ & $(1)$ & $(2)$ & (3) & $(1)$ & $(2)$ & (3) \\
\hline Co-ethnic neighbors' education & $-0.085 * * *$ & $-0.034 * *$ & $-0.055^{* *}$ & $0.273 * * *$ & $0.075^{* * *}$ & $0.136 * * *$ & $0.845^{* * *}$ & $0.227 * * *$ & $0.252 * * *$ \\
\hline & $(0.008)$ & $(0.011)$ & $(0.021)$ & $(0.013)$ & $(0.016)$ & $(0.038)$ & $(0.035)$ & $(0.041)$ & $(0.060)$ \\
\hline Immigrant neighbors' education & $-0.083 * *$ & -0.001 & 0.000 & $0.215 * * *$ & 0.033 & 0.033 & $0.333 * *$ & 0.076 & 0.101 \\
\hline & $(0.028)$ & $(0.038)$ & $(0.037)$ & $(0.043)$ & $(0.059)$ & $(0.058)$ & $(0.118)$ & $(0.169)$ & $(0.170)$ \\
\hline Native neighbors' education & 0.001 & -0.003 & -0.012 & $-0.074 *$ & -0.011 & 0.011 & $-0.504 * * *$ & 0.166 & 0.129 \\
\hline & $(0.022)$ & $(0.053)$ & $(0.054)$ & $(0.035)$ & $(0.092)$ & $(0.084)$ & $(0.116)$ & $(0.287)$ & $(0.282)$ \\
\hline Number of coethnic neighbors (std.) & & & 0.010 & & & -0.032 & & & -0.031 \\
\hline & & & $(0.014)$ & & & $(0.021)$ & & & $(0.032)$ \\
\hline Coethnics' education $\times$ number (std.) & & & -0.048 & & & 0.143 & & & 0.065 \\
\hline & & & $(0.042)$ & & & $(0.074)$ & & & $(0.100)$ \\
\hline Mean of outcome & 0.133 & 0.133 & 0.133 & 0.586 & 0.586 & 0.586 & 0.000 & 0.000 & 0.000 \\
\hline$R^{2}$ & 0.004 & 0.146 & 0.147 & 0.016 & 0.163 & 0.163 & 0.033 & 0.281 & 0.281 \\
\hline Neighborhoood fixed effects & No & Yes & Yes & No & Yes & Yes & No & Yes & Yes \\
\hline Country-of-origin fixed effects & No & Yes & Yes & No & Yes & Yes & No & Yes & Yes \\
\hline Background covariates & No & Yes & Yes & No & Yes & Yes & No & Yes & Yes \\
\hline
\end{tabular}

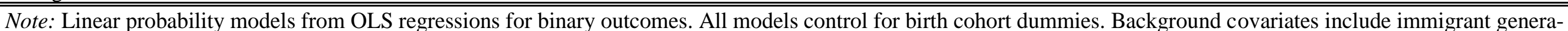

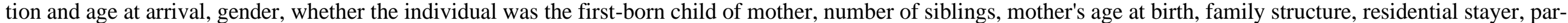

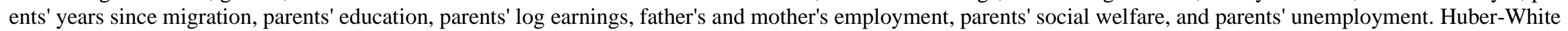
standard errors in parentheses are robust to within-neighborhood clustering and heteroskedasticity.

*** $P<0.01$; ** $P<0.05$; * $P<0.10$ (two-tailed tests) 
Table 5. Estimated effect of coethnic neighbors' education on subcategories of adolescent crime

\begin{tabular}{|c|c|c|c|c|c|c|c|c|c|}
\hline & \multirow{3}{*}{$\begin{array}{l}\text { All } \\
(1)\end{array}$} & \multicolumn{8}{|c|}{ By subcategory of adolescent crime } \\
\hline & & \multirow{2}{*}{$\begin{array}{l}\text { Damages } \\
(2) \\
\end{array}$} & \multirow{2}{*}{$\begin{array}{l}\text { Drugs } \\
(3) \\
\end{array}$} & \multirow{2}{*}{$\begin{array}{l}\text { Sexual } \\
(4) \\
\end{array}$} & \multirow{2}{*}{$\begin{array}{l}\text { Violence } \\
(5)\end{array}$} & \multirow{2}{*}{$\begin{array}{l}\text { Property } \\
(6) \\
\end{array}$} & \multirow{2}{*}{$\begin{array}{l}\text { Economic } \\
(7) \\
\end{array}$} & \multirow{2}{*}{$\begin{array}{l}\text { Traffic } \\
(8)\end{array}$} & \multirow{2}{*}{$\begin{array}{l}\text { Other } \\
(9)\end{array}$} \\
\hline & & & & & & & & & \\
\hline \multirow[t]{2}{*}{ Co-ethnic neighbors' education } & $-0.034 * *$ & -0.009 & -0.013 & -0.002 & $-0.023 * *$ & $-0.017 *$ & 0.000 & $-0.017 * *$ & $-0.021 * *$ \\
\hline & $(0.011)$ & $(0.005)$ & $(0.007)$ & $(0.002)$ & $(0.007)$ & $(0.008)$ & $(0.002)$ & $(0.006)$ & $(0.007)$ \\
\hline Mean outcome & 0.133 & 0.017 & 0.058 & 0.003 & 0.062 & 0.072 & 0.007 & 0.042 & 0.057 \\
\hline$R^{2}$ & 0.146 & 0.059 & 0.096 & 0.047 & 0.099 & 0.103 & 0.034 & 0.088 & 0.096 \\
\hline Number of observations & 43,737 & 43,737 & 43,737 & 43,737 & 43,737 & 43,737 & 43,737 & 43,737 & 43,737 \\
\hline Immigrant neighbors' education & Yes & Yes & Yes & Yes & Yes & Yes & Yes & Yes & Yes \\
\hline Native neighbors' education & Yes & Yes & Yes & Yes & Yes & Yes & Yes & Yes & Yes \\
\hline Neighborhoood fixed effects & Yes & Yes & Yes & Yes & Yes & Yes & Yes & Yes & Yes \\
\hline Country-of-origin fixed effects & Yes & Yes & Yes & Yes & Yes & Yes & Yes & Yes & Yes \\
\hline Background covariates & Yes & Yes & Yes & Yes & Yes & Yes & Yes & Yes & Yes \\
\hline
\end{tabular}

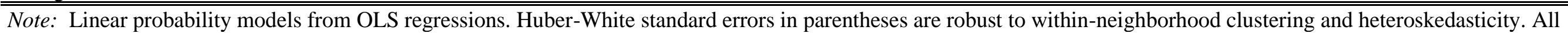
models control for birth cohort dummies and background covariates are the same as in Table 3 .

*** $P<0.001$; ** $P<0.01$; * $P<0.05$ (two-tailed tests) 
Table 6. Estimated effect of coethnic neighbors' education on adolescent crime and upper-secondary completion before and after adjustment for grade point average

\begin{tabular}{llll}
\hline Panel A. Adolescent crime & $(1)$ & $(2)$ & $(3)$ \\
\hline Co-ethnic neighbors' education & $-0.034^{* * *}$ & $-0.034^{* *}$ & -0.019 \\
Grade point average (std.) & $(0.011)$ & $(0.013)$ & $(0.013)$ \\
& & & $-0.065^{* * *}$ \\
$R^{2}$ & & & $(0.003)$ \\
Observations & 0.146 & 0.149 & 0.176 \\
\hline Panel B. Upper-secondary completion & 43891 & 30340 & 30340 \\
\hline Co-ethnic neighbors' education & $(1)$ & $(2)$ & $(3)$ \\
& $0.075^{* * *}$ & $0.075^{* * *}$ & 0.022 \\
Grade point average (std.) & $(0.016)$ & $(0.019)$ & $(0.017)$ \\
& & & $0.237 * *$ \\
$R^{2}$ & & & $(0.004)$ \\
Observations & & & 0.349 \\
\hline Sample & 0.163 & 0.182 & 30,340 \\
Immigrant neighbors' education & 43,891 & 30,340 & Restricted \\
Native neighbors' education & Full & Restricted \\
Neighborhoood fixed effects & Yes & Yes & Yes \\
Country-of-origin fixed effects & Yes & Yes & Yes \\
Background covariates & Yes & Yes & Yes \\
\hline \hline
\end{tabular}

Note: Linear probability models from OLS regressions. Huber-White standard errors in parentheses are robust to within-neighborhood clustering and heteroskedasticity. All models control for birth cohort dummies and background covariates are the same as in Table 3 .

*** $P<0.001 ; * * P<0.01 ; * P<0.05$ (two-tailed tests) 
Table 7. Robustness check conditioning on minimum number of coethnics in neighborhood and stratifying by residential mobility

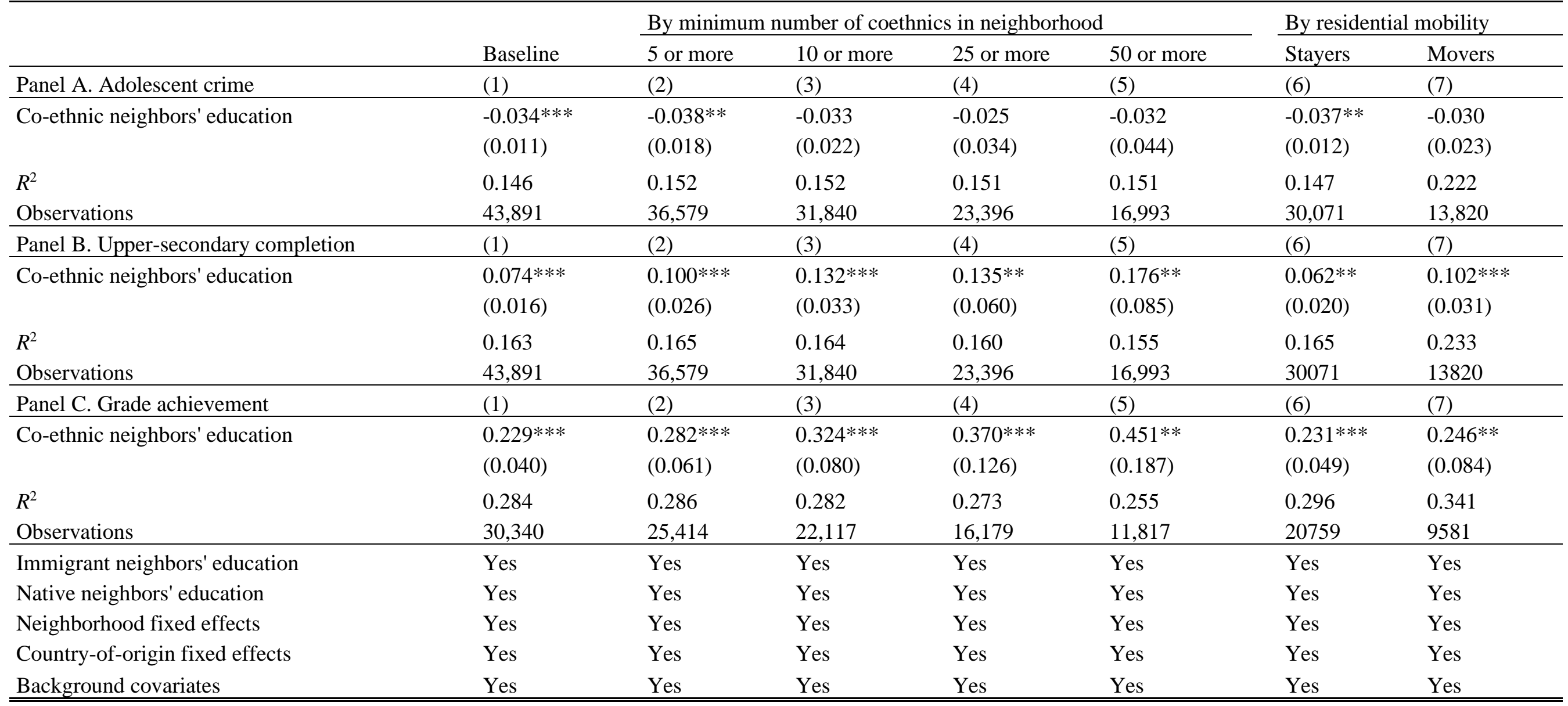

Note: Linear probability models from OLS regressions for binary outcomes. Huber-White standard errors in parentheses are robust to within-neighborhood clustering and heteroskedasticity. All models control for birth cohort dummies and background covariates are the same as in Table 3.

*** $P<0.001$; ** $P<0.01 ; * P<0.05$ (two-tailed tests) 
Table A1. Estimates on background covariates from Table 4, column 2 for all outcomes (OLS regressions)

\begin{tabular}{|c|c|c|c|}
\hline & $\begin{array}{l}\text { Panel A. } \\
\text { Adolescent } \\
\text { crime }\end{array}$ & $\begin{array}{l}\text { Panel B. } \\
\text { Upper-secondary } \\
\text { completion }\end{array}$ & $\begin{array}{l}\text { Panel C. } \\
\text { Grade point } \\
\text { average } \\
\end{array}$ \\
\hline & $(1)$ & $(2)$ & $(3)$ \\
\hline \multicolumn{4}{|c|}{ Immigrant generation (ref. = born in Norway) } \\
\hline Foreign-born, arrival ages 0-6 years & $\begin{array}{l}0.003 \\
(0.006)\end{array}$ & $\begin{array}{l}-0.023 * * \\
(0.007)\end{array}$ & $\begin{array}{l}-0.031 \\
(0.018)\end{array}$ \\
\hline Foreign-born, arrival ages 7-12 years & $\begin{array}{l}0.002 \\
(0.008)\end{array}$ & $\begin{array}{l}-0.060 * * * \\
(0.010)\end{array}$ & $\begin{array}{l}-0.183 * * * \\
(0.026)\end{array}$ \\
\hline Female & $\begin{array}{l}-0.189 * * * \\
(0.005)\end{array}$ & $\begin{array}{l}0.154 * * * \\
(0.005)\end{array}$ & $\begin{array}{l}0.335 * * * \\
(0.012)\end{array}$ \\
\hline First-born child of mother & $\begin{array}{l}-0.019 * * * \\
(0.004)\end{array}$ & $\begin{array}{l}0.041 * * * \\
(0.005)\end{array}$ & $\begin{array}{l}0.126 * * * \\
(0.013)\end{array}$ \\
\hline Number of siblings & $\begin{array}{l}0.007 * * * \\
(0.001)\end{array}$ & $\begin{array}{l}-0.011^{* * * *} \\
(0.002)\end{array}$ & $\begin{array}{l}-0.020 * * * \\
(0.005)\end{array}$ \\
\hline Mother's age at birth & $\begin{array}{l}-0.002 * * * \\
(0.000)\end{array}$ & $\begin{array}{l}0.004 * * * \\
(0.001)\end{array}$ & $\begin{array}{l}0.010 * * * \\
(0.001)\end{array}$ \\
\hline Intact or reconstituted family household & $\begin{array}{l}-0.047 * * * \\
(0.005)\end{array}$ & $\begin{array}{l}0.064 * * * \\
(0.006)\end{array}$ & $\begin{array}{l}0.113 * * * \\
(0.015)\end{array}$ \\
\hline \multicolumn{4}{|c|}{ Parental education (ref. = below upper-secondary) } \\
\hline Upper-secondary completed & $\begin{array}{l}-0.007 \\
(0.005)\end{array}$ & $\begin{array}{l}0.050 * * * \\
(0.008)\end{array}$ & $\begin{array}{l}0.155^{* * * *} \\
(0.016)\end{array}$ \\
\hline Postsecondary degree, short & $\begin{array}{l}-0.025^{* * *} \\
(0.005)\end{array}$ & $\begin{array}{l}0.116^{* * * *} \\
(0.008)\end{array}$ & $\begin{array}{l}0.334 * * * \\
(0.017)\end{array}$ \\
\hline Postsecondary degree, long & $\begin{array}{l}-0.046^{* * *} \\
(0.006)\end{array}$ & $\begin{array}{l}0.156^{* * * *} \\
(0.010)\end{array}$ & $\begin{array}{l}0.506^{* * * *} \\
(0.026)\end{array}$ \\
\hline No education registered & $\begin{array}{l}0.013^{*} \\
(0.006)\end{array}$ & $\begin{array}{l}-0.013 \\
(0.009)\end{array}$ & $\begin{array}{l}0.027 \\
(0.023)\end{array}$ \\
\hline Parents' earnings $(\log )$ & $\begin{array}{l}0.000 \\
(0.001)\end{array}$ & $\begin{array}{l}0.003 * * \\
(0.001)\end{array}$ & $\begin{array}{l}0.009 * * * \\
(0.003)\end{array}$ \\
\hline Father employment & $\begin{array}{l}-0.009 \\
(0.005)\end{array}$ & $\begin{array}{l}0.014 \\
(0.007)\end{array}$ & $\begin{array}{l}0.018 \\
(0.017)\end{array}$ \\
\hline Mother employment & $\begin{array}{l}-0.005 \\
(0.004)\end{array}$ & $\begin{array}{l}0.045 * * * \\
(0.006)\end{array}$ & $\begin{array}{l}0.113 * * * \\
(0.016)\end{array}$ \\
\hline Parents' social welfare & $\begin{array}{l}0.041 * * * \\
(0.005)\end{array}$ & $\begin{array}{l}-0.085^{* * * *} \\
(0.007)\end{array}$ & $\begin{array}{l}-0.203 * * * \\
(0.018)\end{array}$ \\
\hline Parents' unemployment & $\begin{array}{l}0.000 \\
(0.005)\end{array}$ & $\begin{array}{l}-0.033 * * * \\
(0.007)\end{array}$ & $\begin{array}{l}-0.056 * * \\
(0.017)\end{array}$ \\
\hline Parents' years since migration & $\begin{array}{l}0.000 \\
(0.000)\end{array}$ & $\begin{array}{l}0.000 \\
(0.001)\end{array}$ & $\begin{array}{l}0.001 \\
(0.001)\end{array}$ \\
\hline Mean outcome variable & 0.133 & 0.586 & 0.000 \\
\hline$R^{2}$ & 0.146 & 0.163 & 0.281 \\
\hline Number of observations & 43891 & 43891 & 30340 \\
\hline Neighborhood fixed effects & Yes & Yes & Yes \\
\hline Country-of-origin fixed effects & Yes & Yes & Yes \\
\hline
\end{tabular}

Note: Linear probability models from OLS regressions for binary outcomes. All models control for birth cohort dummies. Huber-White standard errors in parentheses are robust to within-neighborhood clustering and heteroskedasticity.

*** $P<0.001 ; * * P<0.01$; * $P<0.05$ (two-tailed tests) 
